\title{
РЕЗУЛЬТАТИ РЕАЛІЗАЦІї КОНЦЕПЦІї РОЗВИТКУ ТЕРНОПІЛЬСЬКОГО ДЕРЖАВНОГО МЕДИЧНОГО УНІВЕРСИТЕТУ ІМЕНІ І. Я. ГОРБАЧЕВСБКОГО НА ШЛЯХУ ЙОГО ВХОДЖЕННЯ У СВІТОВИЙ ОСВІТНІЙ ПРОСТІР
}

\author{
Л. Я. Ковальчук
}

Тернопільський державний медичний університет імені І. Я. Горбачевського

\section{RESULTS OF I. YA. HORBACHEVSKY STATE MEDICAL UNIVERSITY DEVELOPMENT CONCEPT IN THE WAY OF ITS ENTRY INTO THE GLOBAL EDUCATIONAL AREA}

L. Ya. Kovalchuk

\author{
Ternopil State Medical University by I. Ya. Horbachevsky
}

\begin{abstract}
У статті висвітлено результати реалізації Концепції розвитку Тернопільсыкого державного медичного університету імені І. Я. Горбачевського за останні п'ять років.
\end{abstract}

The article deals with the results of implementation of the Concepts of TSMU development for the last five years.

Вступ. Через місяць виповниться п'ять років, як вчена рада університету в результаті аналізу та обговорень прийняла Концепціюрозвитку Тернопільського державного медичного університету імені І. Я. Горбачевського (інтеграція у світовий медичний освітній простір) (27 червня 2006 року, протокол № 19). Вона базувалася на вивченому досвіді викладання та реформування в провідних медичних ВНЗ Європи (Віденському медичному університеті, Словацькому медичному університеті, Шльонській медичній академії, Карловому університеті) та США (Університет Південної Кароліни, Каліфорнійський університет), у які було направлено близько 40 викладачів різних кафедр [1-6].

Необхідність створення Концепції розвитку Тернопільського державного медичного університету імені I. Я. Горбачевського була викликана потребою забезпечення мобільності студентів у Світовому освітньому просторі - в обміні студентів між університетами та впровадження принципів кредитно-модульної системи навчання в організацію навчального процесу в нашому ВНЗ, а також входження Тернопільського державного медичного університету імені I. Я. Горбачевського у Світовий освітній простір, щоб стати учасником формування єдиного ринку медичної освіти і забезпечення мобільності лікарів на світовому ринку праці. Вона поклала початок впрова- дженню нових технологій навчання, змінам у загальній структурі університету і стала основою організації навчального процесу в університеті.

Основна частина. Структура університету, згідно з Концепцією, зазнала принципової реорганізації. Теоретичні кафедри стали базою для створення чотирьох навчально-наукових інститутів, розміщених у відповідних корпусах університету. Окремим підрозділом, що поєднує теоретичну і практичну підготовку середнього медичного персоналу, а також бакалаврів та магістрів сестринської справи, $є$ ННІ медсестринства. Для оптимізації діяльності кожного ННI у сферах навчання студентів та наукової роботи створено вчені ради інститутів. 3 цією ж метою окремі вчені ради створено при всіх факультетах університету. Підвищено роль органів громадського самоврядування у керівництві підрозділами. На кожному факультеті найвищим органом управління $€$ конференція (загальні збори) трудового колективу, яка обирає вчену раду факультету та вирішує інші принципові питання. Діяльність вченої ради факультету, ННI, клінічних кафедр регулюється відповідним Положенням, затвердженим вченою радою університету та ректором університету. Щорічно кожен декан факультету та директор інституту звітує на вченій раді університету за виконану підпорядкованим йому підрозділом роботу.

(с) Л. Я. Ковальчук 
Зазнала змін і структура клінічних кафедр відповідно до принципів профільності та укрупнення.

Професорсько-викладацький склад та навчальнодопоміжний персонал університету за останні роки виконали надзвичайно великий обсяг навчально-методичної роботи. На веб-сторінці кожної кафедри розміщена вся необхідна інформація, що забезпечує можливість повноцінної підготовки студентів до занять.

Кожен студент на початку навчального року отримує матрикул, у якому є перелік практичних навичок, які потрібно засвоїти відповідно до вимог Галузевих стандартів вищої освіти. Впроваджена у навчальний процес і ефективно функціонує методика навчання “єдиного дня”. Викладачі та студенти оцінюють позитивно іï використання, оскільки вона дозволяє студентам зосередити свої зусилля на вивченні протягом заняття однієї дисципліни і виключити затрати часу та коштів на переїзди між кафедрами i, відповідно, повністю виключити їх запізнення [7].

Протягом 6-7 год перебування на кафедрі студенти мають можливість виконати великий обсяг практичної роботи, грунтовніше опанувати практичні навички, приділити більше часу самостійній курації хворих. Дана методика сприяє ефективному впровадженню циклової системи навчання, створенню тематичних навчальних кімнат та оснащенню їх сучасним обладнанням, більш повноцінному забезпеченню занять тематичними хворими, ефективному використанню матеріально-технічної бази кафедри, особливо у клініках. При такій системі організації навчального процесу у викладача $\epsilon$ можливість провести детальне обговорення зі студентами найважливіших питань теми, що проходить у формі вільної дискусії, в якій беруть активну участь всі присутні на занятті студенти. При відповідній мотивації і досконалому матеріально-технічному забезпеченні навіть недостатньо підготовлений на початок заняття студент після його завершення володітиме необхідним обсягом базової інформації $з$ даної теми. Незаперечними перевагами впровадження даної методики $\epsilon$ також суттєве зменшення кількості пропусків студентами занять без поважних причин, можливість скорочення тривалості семестрів [8,9].

Методика “єдиного дня” вимагає належного забезпечення занять навчально-методичною літературою. Для цього, крім університетської бібліотеки, у кожному навчально-науковому інституті та на клінічних кафедрах створено бібліотеки з потрібною навчальною літературою на паперових та електронних носіях і періодичними виданнями видавництва "Укрмедкнига”, де студенти усіх факультетів можуть отри- мати всі необхідні підручники і навчальні посібники щодня 39 год ранку до 9 год вечора. Фонд бібліотек постійно поповнюється навчальними компакт-дисками, відеофільмами, сучасною періодичною та науковою літературою. На всіх кафедрах університету студенти мають доступ до електронних навчальних матеріалів, розміщених на WEB-порталі університету, зокрема розкладів занять, робочих планів дисциплін, презентацій лекцій, методичних рекомендацій та матеріалів підготовки до практичних занять, банків навчальних таблиць та відеофільмів тощо, що суттево полегшує студентам пошук сучасної інформації 3 предмета та підвищує якість іiі засвоєння. 3 метою поліпшення засвоєння студентами навчального матеріалу під час проведення практичних занять для кафедр університету придбано 40 комплектів відеосистеми 3 широкоформатними моніторами. У 13 лекційних аудиторіях і на окремих кафедрах установлено 32 відеопроектори. Усі 39 комп'ютерних класів підключено до мережі Інтернет та Інтранет. Усього на сьогодні в університеті налічується 866 комп'ютерів, із них 851 підключено до мережі Інтернет. 3'явилась також можливість використання WiFi-доступу (безпровідного Інтернету), яким широко користуються викладачі та студенти, які мають портативні комп'ютери.

Незаперечним цінним здобутком реформування системи навчання у нашому університеті $\epsilon$ впровадження Z-системи навчання, що дозволяє студентам уже 3 перших курсів відчути себе у ролі майбутніх лікарів, максимально опанувати знання та отримати практичні навички, які наближають їх впритул дорівня вимог, необхідних для майбутньої професії.

3 другого курсу навчання на медичному факультеті почали вводити циклову систему навчання, що дозволяє грунтовніше опанувати предмет викладачам, які відповідають за певний цикл даної дисципліни.

Створено потужну базу тестових завдань, яка на сьогодні налічує близько 500 тисяч тестів, що унеможливлює їх механічне запам'ятовування. Її використовують для перевірки рівня знань на кафедрі та при проведенні семестрового комплексного тестового іспиту.

Студенти мають можливість звечора напередодні заняття перевірити свої знання та отримати оцінку за системою Moodle, відповівши на 24 тестові завдання, підбір яких з існуючої бази даних здійснює оnline автоматизована комп’ютерна система. Це дозволяє скоротити тривалість заняття, і вже 314 год студенти можуть працювати за своїм індивідуальним планом. Якщо на початку впровадження оцінювання за системою Moodle викладачам доводилося 
агітувати студентів за їі використання, то тепер самі студенти турбуються про те, щоб завдання на наступний день були вчасно активовані.

Таким чином, за наявності бажання до навчання i самодисципліни тепер студенти мають значно більше часу та можливостей для самостійної роботи, ніж їх попередники. А основою освіти, як уже доведено, є самостійна робота, яка створює базу знань, завдяки якій можна успішно складати тести будь-якої складності.

Однією з основних вимог Стандартів і рекомендацій щодо забезпечення якості освіти у Європейському просторі вищої освіти (2006) є прозорість оцінювання знань студентів, що є запорукою високої об' єктивності при визначенні якості знань та навичок, отриманих ними під час навчання [10]. У Тернопільському державному медичному університеті імені I. Я. Горбачевського вперше серед вищих медичних (фармацевтичного) навчальних закладів України задля незалежного та об'єктивного оцінювання знань студентів з 2006-2007 навчального року впроваджено комплексний семестровий контроль рівня знань студентів. Він включає складання практичних навичок, вказаних у матрикулі, складання єдиного комплексного тестового іспиту, а для студентів старших курсів - ще й складання об' єктивно-структурованого клінічного іспиту (ОСКІ).

Досвід проведення єдиного комплексного тестового іспиту підтвердив його високу об' єктивність, дозволив зменшити навантаження на професорсько-викладацький склад кафедр і звільнити його від рутинної роботи $з$ приймання іспитів, а також значно скоротив час на їх складання студентами - до двох днів замість складання 11-15 модулів (медичний факультет), при- чому більшість 3 них припадала на останні дні семестру, або 2-4 іспитів протягом двох-трьох тижнів (фармацевтичний і стоматологічний факультети) [11].

Незалежне тестування унеможливило і зробило абсолютно недоцільним будь-який тиск на викладачів під час іспитів, а на кафедрах при такій системі оцінювання ніколи не з' являться так звані “ходоки”, які проситимуть кращі оцінки для деяких студентів.

Семестрові комплексні тестові іспити визнано однією з найбільш об'єктивних форм контролю рівня знань студентів, що позбавлена впливу суб' єктивного (людського) чинника. Вони органічно ввійшли у навчальний процес нашого університету і визнані професорсько-викладацьким складом та студентами. Результати цих іспитів постійно аналізуються, що дозволяє кафедрам вдосконалювати тестові завдання, відкидаючи ті, які є невалідними, та вдосконалювати форми проведення такого іспиту. Зокрема, здійснено розподіл семестрового комплексного тестового іспиту на дві частини. Це створило оптимальні умови для мобілізування студентами своїх інтелектуальних можливостей та повноцінного розв' язання запропонованих завдань, що відразу позитивно позначилося на результатах складання іспиту (рис. 1).

Збільшення бази тестів до 500 тисяч ситуаційних задач та рисунків не дозволяє зазубрювати відповіді, а вимагає щоденного наполегливого засвоювання та глибокого розуміння суті теоретичного матеріалу, а також освоєння на високому рівні практичних навичок, які лежать в основі вирішення ситуаційних задач та розпізнавання рисунків.

Для вдосконалення і чіткої організації комплексних тестових іспитів в університеті створено навчально-

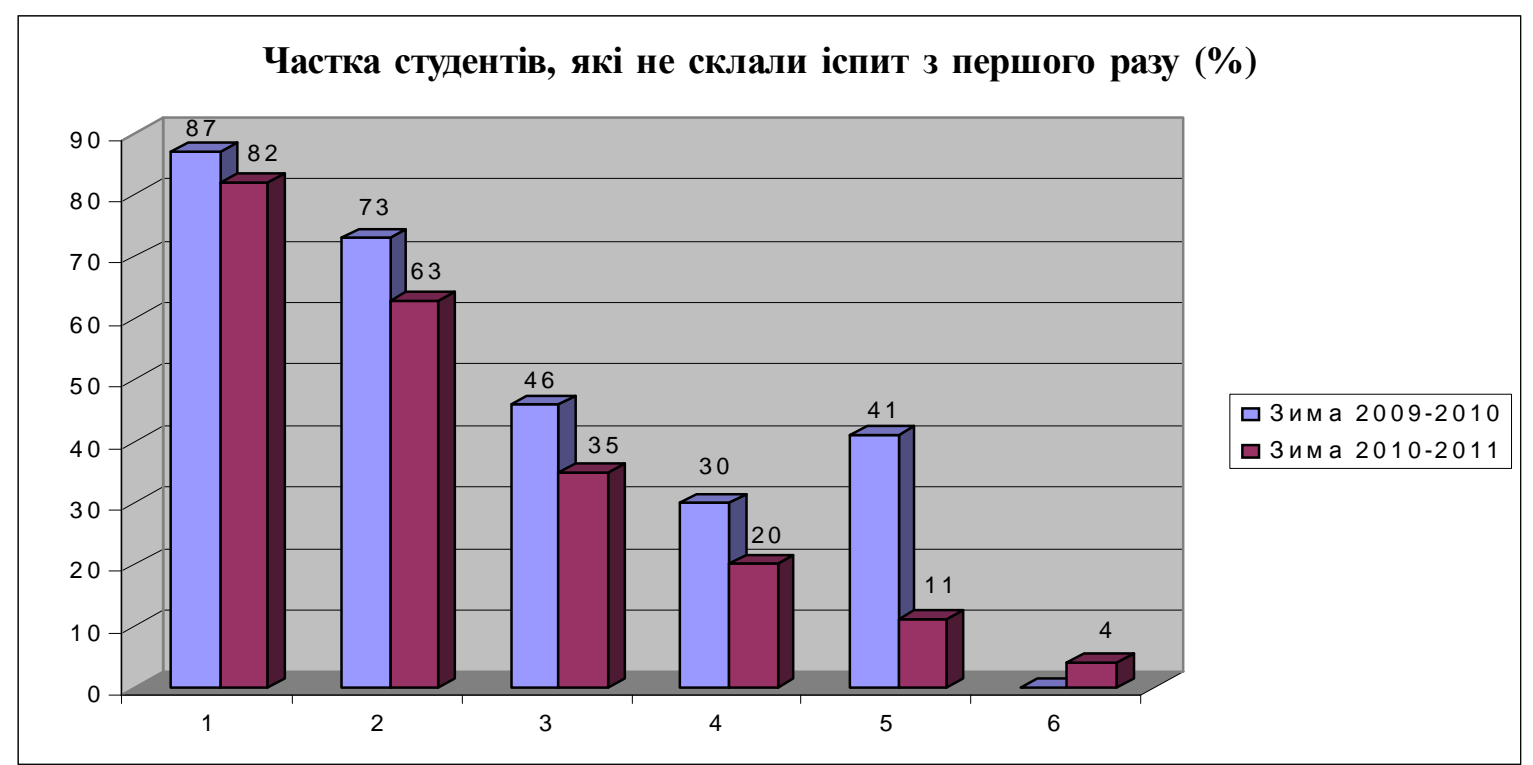

Puc. 1. Частка студентів, які не склали єдиний тестовий іспит з першої спроби (2009-2010 н. p. та 2010-2011 н. p.). 
науковий відділ незалежного тестування знань студентів на чолі з досвідченим викладачем доцентом П. Р. Сельським. Відділу підпорядковані вісім постійно діючих комісій, які безпосередньо готують усі матеріали для комплексних тестових іспитів і проводять їх на різних курсах. До складу комісій увійшли професори і доценти університету (по 4 у кожній комісіі), які мають великий досвід методичної та управлінської роботи.

Центр незалежного тестування знань студентів оснащений сучасною множильною технікою для створення буклетів тестових завдань для кожного студента й окремим комп'ютером-сервером із системним блоком підвищеної потужності, який має механічнута електронну системи захисту від несанкціонованого доступу і зберігається у спеціальній шафі, що опечатується і відкривається під час сесії тільки у присутності членів екзаменаційних комісій. До комп'ютерасервера під'єднані всі комп'ютери, які встановлені у відділі. Це забезпечує повну ізоляцію комп'ютерної мережі відділу від інших мереж, у т.ч. і бездротових. Крім того, у відділі встановлено відеоспостереження $з$ цілодобовим записом інформації та категорично заборонено користуватися будь-якими електронними пристроями - мобільними телефонами, флеш та іншими картами пам'яті, камерами і под.

Уся робота з підготовки та сам процес іспиту чітко регламентовані затвердженими інструкціями, дотримання яких забезпечує повну прозорість процесу від початку формування буклетів до отримання студентом об' єктивної оцінки.
Виставлення оцінки, яке здійснює комп'ютер, відбувається згідно з інструкцією МОЗ України за формулою: 60 \% загальної оцінки за кожну дисципліну складає оцінка за поточну успішність 3 неї протягом семестру і 40 \% - за складання відповідного модуля.

Рік тому Ухвалою вченої ради університету відсоток правильних відповідей під час складання семестрових комплексних тестових іспитів був піднятий до державного стандарту (50,5 \%), за яким уже 10 років Міністерство охорони здоров'я України здійснює централізований державний контроль за якістю підготовки студентів і випускників медичної та фармацевтичної галузі за допомогою ліцензійних інтегрованих іспитів.

Отримані в результаті аналізу складання іспитів дані свідчать про те, що студенти, які навчаються за бюджетні кошти, іспити складають краще, ніж студенти, що навчаються за контрактом (рис. 2). Це закономірно і ще раз підтверджує об' єктивність оцінювання знань, адже при вступі до університету студенти, які вступають на бюджетну форму навчання, іспити складають краще.

Також прослідковується загальна тенденція до отримання вищих оцінок студентами старших курсів медичного та стоматологічного факультетів протягом навчального року та на семестровому тестовому іспиті порівняно зі студентами 1-2 курсів. На старших курсах зазначених факультетів студенти освоюють професійно орієнтовані клінічні дисципліни, до вивчення яких вони вже отримали грунтовну теоретичну підготовку на молодших курсах. Про об’ єктивність

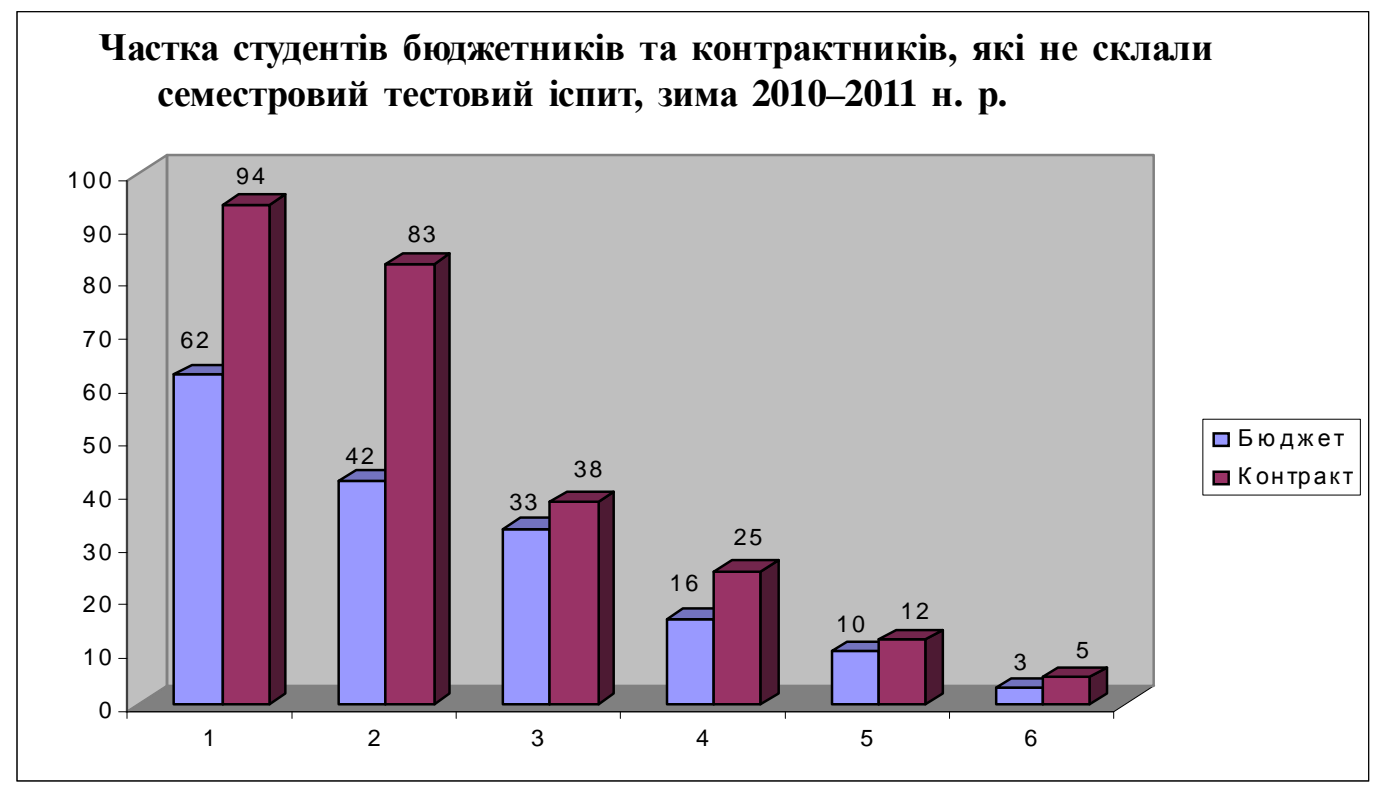

Puc. 2. Результати складання комплексного тестового іспиту студентами, які навчаються за бюджетні кошти і за контрактом. 
комплексного іспиту свідчить те, що у більшості випадків оцінки, які отримують студенти на іспиті, мають незначні відхилення від оцінок їх поточної успішності. Зрозуміло, що там, де на об'єктивність оцінювання знань не впливають суб'єктивні фактори, немає i підгрунтя для корупції. Останнє стало вагомим чинником щодо збільшення припливу на навчання у наш університет в останні роки як вітчизняних, так і іноземних студентів.

У 2010-2011 навчальному році в університет вступило 553 нових студенти. 3 них на 1-й курс - 528 (207- на медичний факультет, 44 - на фармацевтичний, 73 на стоматологічний, 108 - на медсестринство, 3 них 73 - на дистанційну форму навчання, 96 - на підготовче відділення). 25 студентів перевелося до нас 3 інших університетів.

Як видно з даних, наведених на рисунку 3 , у 2011 році, порівняно з 2010, кількість студентів на 1-му курсі зросла, відповідно, на медичному, фармацевтичному, стоматологічному факультетах, в Інституті медсестринства та на підготовчому відділенні на 59, 267, 33,46 i $12 \%$.

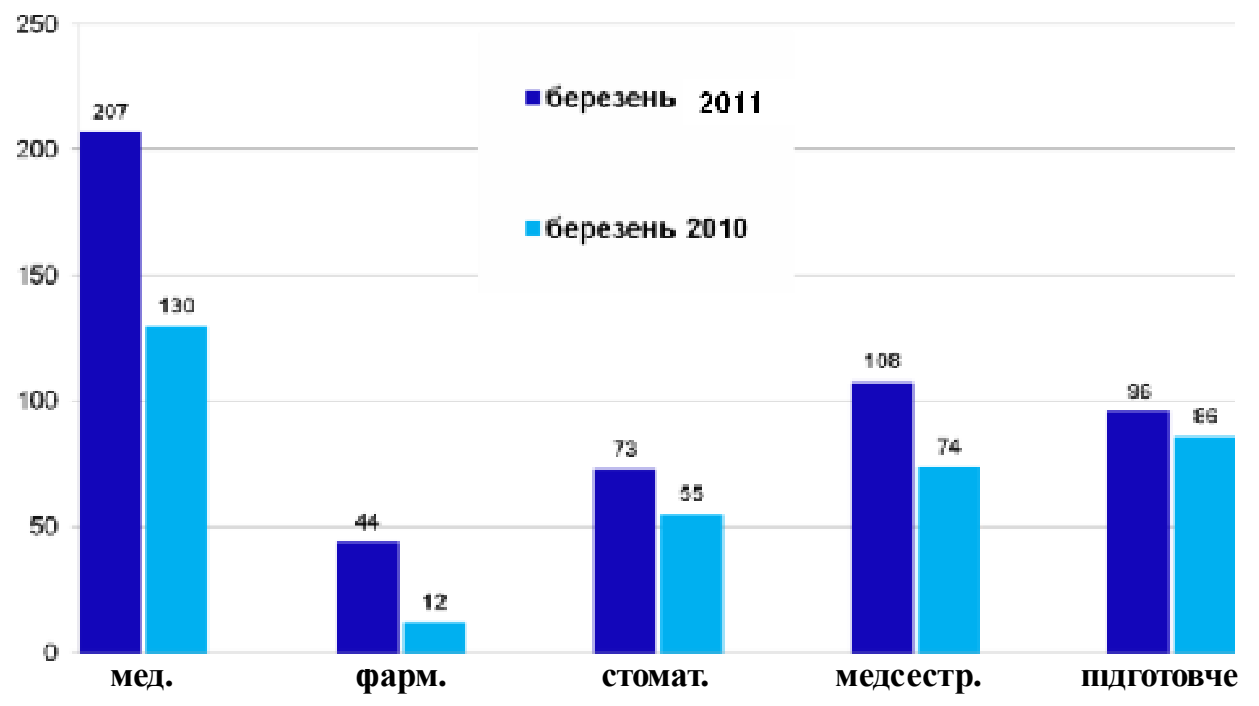

Puc. 3. Динаміка кількості студентів на 1-му курсі за 2010-2011 роки.

Динаміку зростання кількості іноземних студентів у Тернопільському державному медичному університеті імені І. Я. Горбачевського за 13 років (у період 1999-2011 років) відображено на рисунку 4. Сьогодні ї загальна кількість становить 1053 особи, з них англійською мовою навчається, якщо не брати до уваги підготовче відділення і студентів дистанційної форми навчання, $91 \%$.

31053 іноземних студентів навчаються: 552 - на медичному факультеті, 76 - на фармацевтичному, 142 - на стоматологічному, 187 - на медсестринстві, 96 - на підготовчому відділенні. Для порівняння, на цей час у минулому році в університеті було 815 іноземних студентів.

Розпорядженням Кабінету Міністрів України від 23 грудня 2009 року № 1571-р. підтримано пропозиції Міністерства охорони здоров'я, Тернопільської обласної ради та Тернопільської облдержадміністрації сто- совно реалізації пілотного проекту щодо створення Університетської лікарні при Тернопільському державному медичному університеті імені I. Я. Горбачевського. На сьогодні в Тернополі Університетська лікарня успішно функціонує, що створило додаткові можливості для високоякісного навчання студентів на клінічних кафедрах.

Удосконаленню практичної підготовки студентівмедиків значною мірою сприяе створення в межах Загальнодержавної програми розвитку первинної медико-санітарної допомоги на засадах сімейної медицини навчально-практичних центрів первинної медико-санітарної допомоги та навчально-практичних центрів реабілітації і догляду за людьми похилого віку. Створення таких центрів не лише поліпшує систему догляду за людьми похилого віку, які перебувають у групах ризику й потребують допомоги, але й навчає майбутніх лікарів гуманного ставлення до своїх 


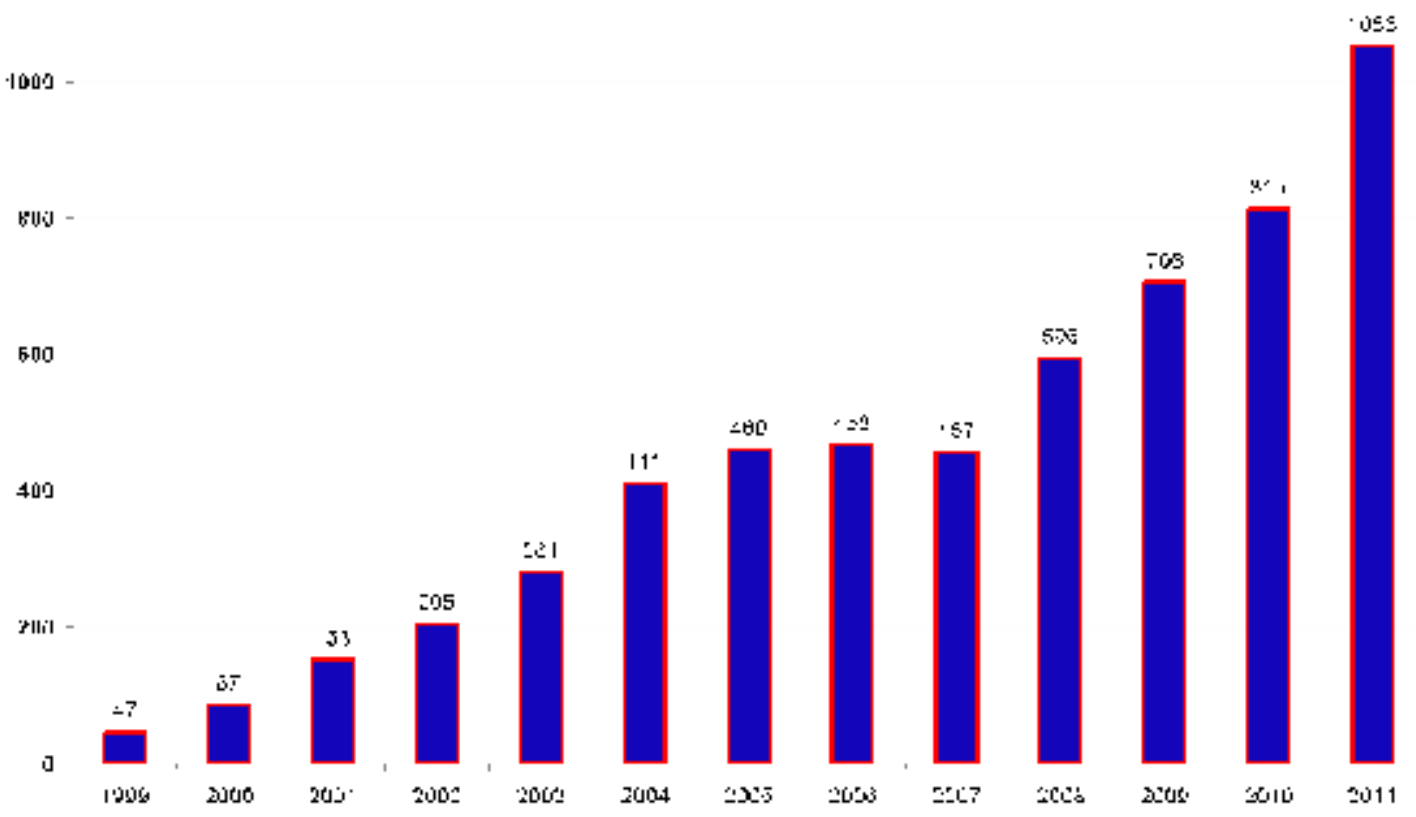

Puc. 4. Динаміка зростання кількості іноземних студентів у Тернопільському державному медичному університеті імені І. Я. Горбачевського за 13 років.

пацієнтів та людей похилого віку, незаперечного дотримання ними високих морально-етичних принципів у майбутній фаховій діяльності.

Інформація про чітко налагоджену систему вищої медичної освіти у ТДМУ, повну об'єктивність оцінювання знань студентів не лише розповсюджується серед мешканців України, але й передається іноземними студентами та випускниками нашого університету своїм співгромадянам. Зросла зацікавленість відповідних структур іноземних країн, що відповідають за освітні процеси, налагодженням тісної взаємовигідної співпраці з нашим університетом. Про це свідчить ряд зустрічей, що відбулися за останні роки.

Було підписано та реалізовано угоди про співпрацю 3 медичними університетами країн Свропи і США, зокрема з Віденським медичним університетом (Австрія), Шльонською медичною академією (Польща), Словацьким медичним університетом (Словаччина), Технічним університетом Дрездена (Німеччина), Карловим університетом (Чехія), Університетом Південної Кароліни (США) і рядом інших. Десятки викладачів ТДМУ мали змогу стажуватися і підвищувати свою наукову кваліфікацію та викладацьку майстерність у цих навчальних закладах.

У грудні 2010 року візит до Тернопільського державного медичного університету імені І. Я. Горбачевського здійснили представники Медичної ради
Малайзії у складі директора Коледжу Лінкольна (Куала-Лумпур) др. Амія Бхаумік і декана др. Датук Абдул Гані. Були проведені перемовини з ректором університету, в результаті чого підписана Угода про співпрацю між Коледжем Лінкольна, який є вищим медичним навчальним закладом, що розміщується у столиці Малайзії Куала-Лумпур, і Тернопільським державним медичним університетом імені І. Я. Горбачевського. У процесі візиту гості ознайомилися 3 умовами проживання і навчання іноземних студентів у Тернопільському медуніверситеті, побували в теоретичних корпусах і Університетській лікарні. Під час перемовин малайзійську делегацію ознайомили 3 новаторськими методами навчання студентів у Тернопільському медуніверситеті. Згідно з підписаною Угодою, Коледж Лінкольна зобов' язується приймати малайзійських студентів і відправляти їх для подальшого навчання в Тернопіль (за рік близько 100 студентів на медичну програму, до 100 студентів на стоматологічну та до 100 студентів на фармацевтичну). Після успішного закінчення університету малайзійським студентам вручатимуть дипломи як Тернопільського державного медичного університету, так і Коледжу Лінкольна. При цьому Малайзійська сторона (Медична рада Малайзії, Міністерство охорони здоров'я Малайзії) матиме право в будь-який час відвідати з інспекцією Тернопільський державний медичний університет для контролю якості навчання студентів з Малайзії. 
27-28 лютого 2011 року повторно відбувся аналогічний візит, під час якого члени Медичної ради Малайзії зустрілися з ректором, проректорами та деканами Тернопільського державного медичного університету. В ході зустрічі ректор університету ознайомив гостей 3 новітніми методами викладання та оцінювання студентів в університеті й комп'ютерними технологіями, впровадженими в університеті. Гості відвідали ряд теоретичних кафедр, а також Університетську лікарню та Інститут медсестринства. Члени малайзійської делегації були приємно вражені умовами, створеними в університеті для навчання $\mathrm{i}$ проживання іноземних студентів, ізапевнили, що сприятимуть позитивному вирішенню питання щодо визнання Тернопільського державного медичного університету Медичною радою Малайзії. На сьогодні наш університет отримав позитивне рішення відповідного комітету Медичної ради Малайзії, i зараз готується великий пакет документів для Міністерства освіти Малайзії.

Університет також відвідали представники посольств Індії, Нігерії, Гани, з якими обговорювалися питання щодо залучення студентів 3 відповідних країн до нас на навчання.

Підвищенню престижу Тернопільського державного медичного університету на міжнародній арені сприяє також налагодження зв' язків із закордонними науковими медичними колами. На початку березня 2010 року делегація ТДМУ в складі ректора чл.-кор. НАМН України, проф. Л. Я. Ковальчука, завідувача кафедри медичної біохімії іклініко-лабораторної діагностики проф. М. М. Корди, завідувача кафедри онкологіi, променевої діагностики і терапії та радіаційної медицини проф. І. Й. Галайчука, а також завідувача експериментальної онкологічноїлабораторіїНаціонального інституту раку канд. біол. наук Н. М. Храновської перебувала 3 візитом у Науковому інститугі онкології Університету Клемсона (Південна Кароліна, США). У березні 2011 року в нашомууніверситетіперебувала делегація із США у складі керівника компаніїOncolix Inc. Майкла Редмана іпрезидента компанії Nurses International, LLC Білла Колемана. Компанія розробила новий препарат "Проланта", який має виражені протиракові властивості й у перспективі планується для використання з метою лікування раку грудей, яєчників і ендометрія. Проведено перемовини між ректором університету чл.-кор. НАМН України, проф. Л. Я. Ковальчуком і паном М. Редманом щодо партнерства і наукового співробітництва в галузі онкології між Тернопільським державним медичним університетом імені І. Я. Горбачевського і компанією Oncolix Inc., зокрема досягнута домовленість про можливість проведення клінічних досліджень препарату “Проланта" у Тернопільському державному медичному університеті.

Зростання іміджу ТДМУ в Україні та за кордоном і підвищення припливу іноземних студентів, ут. ч. і тих, хто хоче навчатися за дистанційним методом, збільшило надходження до спеціального фонду в частині оплати освітніх послуг (рис. 5).

3 даних, які наведено на рисунку 4, видно, що загалом надходження за оплату навчання за період 20062010 років зросли у 2,9 раза, а порівняно з минулим роком - в 1,4 раза.

Майжеполовина всіх коштів, що надійшли за оплату навчання у 2010 році, це оплата навчання іноземних

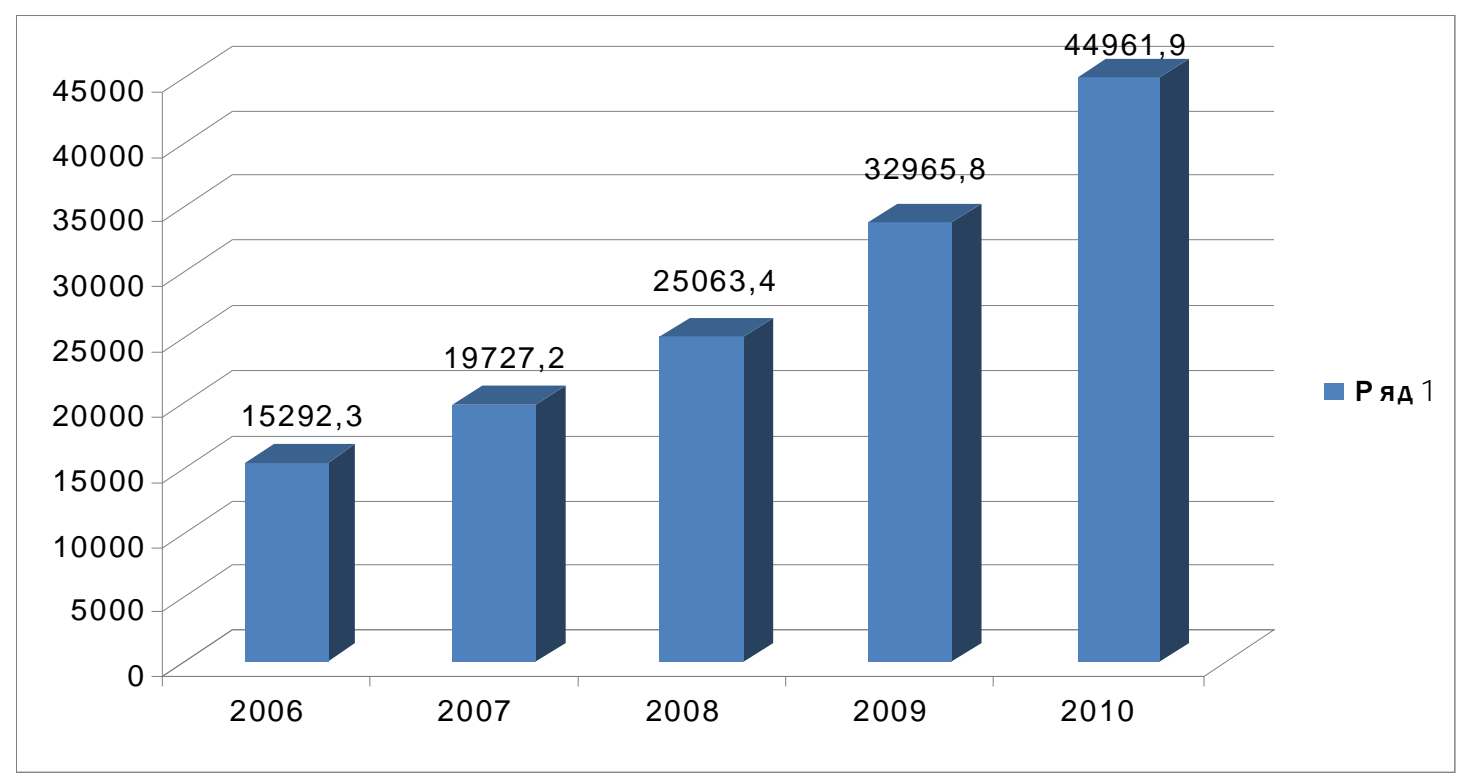

Puc. 5. Оплата освітніх послуг в динаміці (у тис. грн). 
студентів, яка також стрімко зростає по роках (рис. 6). Зокрема, за 5 останніх років надходження збільшились у 7,5 раза, а порівняно з минулим роком -в 1,5 раза.

Це відкриває перспективи для розширення i зміцнення навчальної матеріально-технічної бази. Так, на 2011 рік виділено кошти на реконструкцію з надбудовою бібліотеки університету (вул. Січових стрільців, 8) в сумі 1 млн 200 тис. гривень. Заплановано нове будівництво навчально-практичного центру первинної медико-санітарної допомоги у с. Кокошинці Гусятинського району загальною вартістю 457 тис. 310 гривень. 50 тис. гривень виділено на перерахунок кошторису для введення в дію геронтологічного відділення.
Створено титульний перелік приміщень університету для проведення капітального ремонту в 2011 році, в який ввійшли корпуси № 1 (майдан Волі, 1), № 2 (вул. Руська, 12) та № 5 (вул. Словацького, 2), а також чотири корпуси НОК "Червона калина" та навчально-практичний центр первинної медико-санітарної допомоги у с. Увисла Гусятинського району. Загальна сума лишена проведення капітального ремонту склала 3 млн 293 тис. 250 гривень. За 2010 рік на придбання обладнання для кафедр університету було використано 2501983 гривень.

Продовжується оснащення кафедр університету новими сучасними навчальними приладами та апаратурою для проведення наукових досліджень.

\section{Надходження оплати за навчання від іноземних студентів}

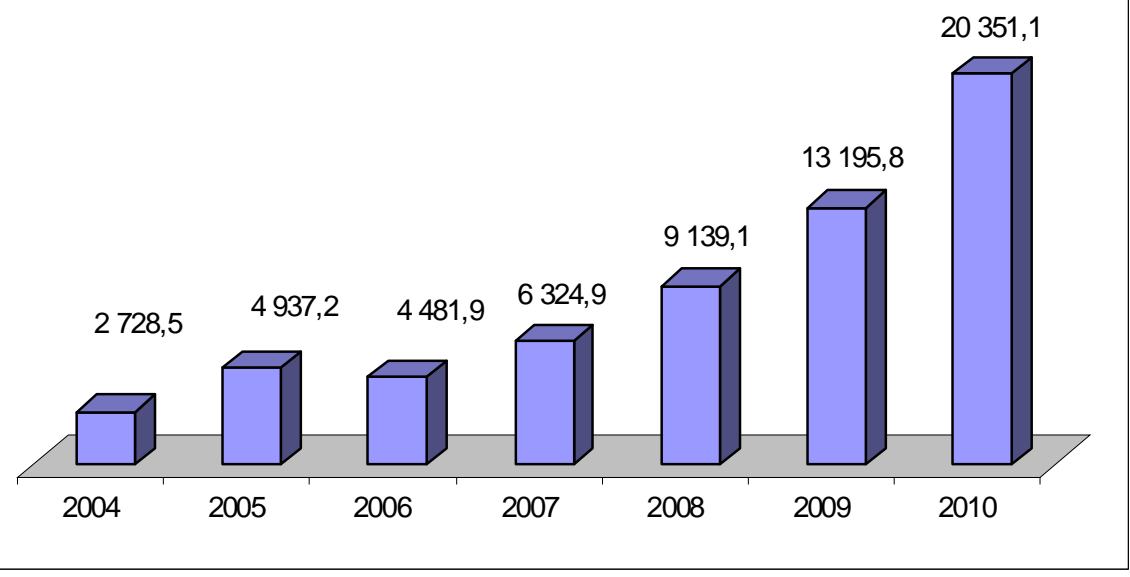

Puc. 6. Надходження до спеціального фонду в частині оплати навчання іноземними студентами (у тис. грн).

Висновки: 1. Усі положення Концепції розвитку Тернопільського державного медичного університету імені І. Я. Горбачевського на шляху його входження у Світовий освітній простір, розробленої та затвердженої п’ ять років тому, успішно реалізуються.

2. Підтвердило свою ефективність введення Z-системи та методики “єдиного дня" при організації навчального процесу за кредитно-модульною системою.

3. Успішне складання семестрових комплексних тестових іспитів нашими студентами є об'єктивною та незалежною складовою системи оцінювання знань студентів, запорукою досягнення ними рівня вимог, що установлені Галузевими стандартами вищої освіти, та усунення підгрунтя для корупції.

4. Зростання іміджу ТДМУ в Україні та за кордоном і підвищення припливуна навчання іноземних студентів, у тому числі тих, хто хоче навчатися за дистанційним методом, збільшило доходи університету та створило фінансові умови для зміцнення навчальної матеріально-технічної бази, оснащення кафедр університету новими сучасними навчальними приладами та апаратурою для проведення наукових досліджень, проведення капітального ремонту корпусів, реконструкції з надбудовою бібліотеки університету, будівництва нового навчально-практичного центру первинної медико-санітарної допомоги у с. Кокошинці Гусятинського району, введення у дію геронтологічного відділення.

5. Створення Тернопільської університетської лікарні, відкриття навчально-практичних центрів первинної медико-санітарної допомоги та навчальнопрактичних центрів реабілітації д догляду за людьми похилого віку стали черговим етапом на шляху інтеграції Тернопільського державного медичного університету імені І. Я. Горбачевського у Світовий медичний простір, а також невід'ємною частиною підготовки висококваліфікованих спеціалістів. 